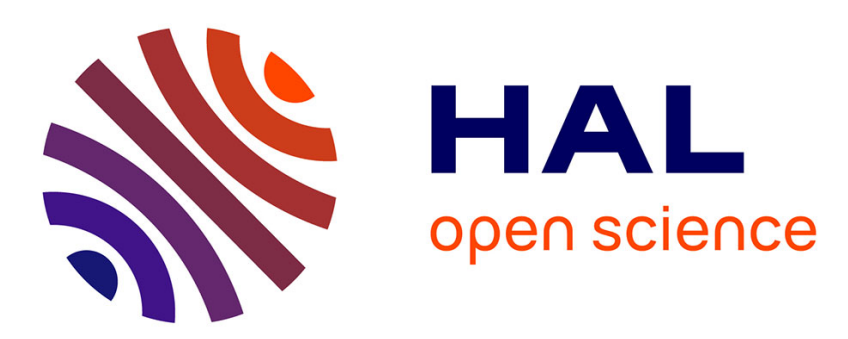

\title{
Solidification of polycrystalline silicon ingots : simulation and characterization of the microstructure
}

\author{
P. Lay, G. Nouet, M. Coster, L. Chermant, J.L. Chermant
}

\section{To cite this version:}

P. Lay, G. Nouet, M. Coster, L. Chermant, J.L. Chermant. Solidification of polycrystalline silicon ingots: simulation and characterization of the microstructure. Revue de Physique Appliquée, 1987, 22 (7), pp.549-555. 10.1051/rphysap:01987002207054900 . jpa-00245574

\section{HAL Id: jpa-00245574 https://hal.science/jpa-00245574}

Submitted on 1 Jan 1987

HAL is a multi-disciplinary open access archive for the deposit and dissemination of scientific research documents, whether they are published or not. The documents may come from teaching and research institutions in France or abroad, or from public or private research centers.
L'archive ouverte pluridisciplinaire HAL, est destinée au dépôt et à la diffusion de documents scientifiques de niveau recherche, publiés ou non, émanant des établissements d'enseignement et de recherche français ou étrangers, des laboratoires publics ou privés. 


\title{
Solidification of polycrystalline silicon ingots : simulation and characterization of the microstructure
}

\author{
P. Lay $\left({ }^{*}\right)$, G. Nouet, M. Coster, L. Chermant and J. L. Chermant \\ Laboratoire d'Etudes et de Recherches sur les Matériaux, ISMRa, Université, 14032 Caen Cedex, France \\ (*) Photowatt Int. S.A., 6, rue de la Girafe, BP 5117, 14043 Caen Cedex, France \\ (Reçu le 20 novembre 1986, accepté le 13 mars 1987)
}

\begin{abstract}
Résumé. - La morphologie du silicium polycristallin obtenu par solidification dirigée est très hétérogène et ne peut pas être analysée par les méthodes globales d'analyse quantitative d'images. Par contre il est possible d'utiliser la fonction $P(l)$ qui donne accès aux distributions de tailles en nombre, $F(l)$, et en mesure, $G(l)$. Les résultats obtenus sur une simulation d'apparition de nouveaux grains à un stade donné de la croissance, ont permis de montrer que la pente à l'origine de la distribution en nombre, $F(l)$, est très sensible à une germination secondaire.
\end{abstract}

Abstract. - Polycrystalline silicon prepared by directional solidification exhibits a very heterogeneous morphology. Consequently the global methods of quantitative image analysis are not applicable. On the contrary, the $P(l)$ function gives access to the size distribution in number $F(l)$ and in weight $G(l)$. For a given stage of the growth, the effect of new grains was simulated and was seen to modify markedly the slope of the size distributions at the origin.

\section{Introduction.}

The most important development in silicon solar cells is due to the substitution of monocrystalline by polycrystalline silicon in order to reduce the cost. Polycrystalline silicon is prepared by various techniques : sheet or ribbon growth, casting or directional solidification. Ribbon technologies have been studied most widely and, as may be expected, further development of these highly sophisticated methods is very slow. In addition equipment for casting and directional solidification is simpler and consequently ingots (HEM, SILSO, POLYX, ...) can now be prepared effectively.

In the last few years, Photowatt Int. S.A. and Laboratoires de Marcoussis-C.G.E. have designed and developed the directional solidification of polycrystalline silicon (POLYX). The capacity of the initial furnace was about $1 \mathrm{~kg}$ and today, 50 to $60 \mathrm{~kg}$ of silicon can be melted and crystallized. The process has been optimized to maintain the constant quality and the good reproductibility of the microstructure. In such microstructures, the grain size may vary considerably and thus classical and local parameters used in quantitative image analysis [1] are no longer applicable.
The aim of this paper is to relate the crystallization conditions and the resultant morphology using quantitative image analysis with the $P(l)$ function and simulation of nucleation.

\section{Method of solidification.}

The method used is based on Bridgman method. It consists in melting the silicon in a graphite crucible using induction heating furnace. The crucible is well insulated to reduce heat loss. The lower part of the insulation can be retracted.

Crystallization is initiated by displacing the bottom insulation of the furnace. No seed crystal is used. In order to maintain a plane solid/liquid interface, the heating power is maintained constant.

The removal of the latent heat of melting at the base of the furnace is controlled by the shift of the insulation. By controlling these various parameters, it is possible to obtain the crystalline quality required for this material $[2,3]$.

\section{Microstructure and selection of the morphological parameters.}

The directional removal of latent heat results in 
unidirectional solidification with a typical columnar structure (Fig. 1).

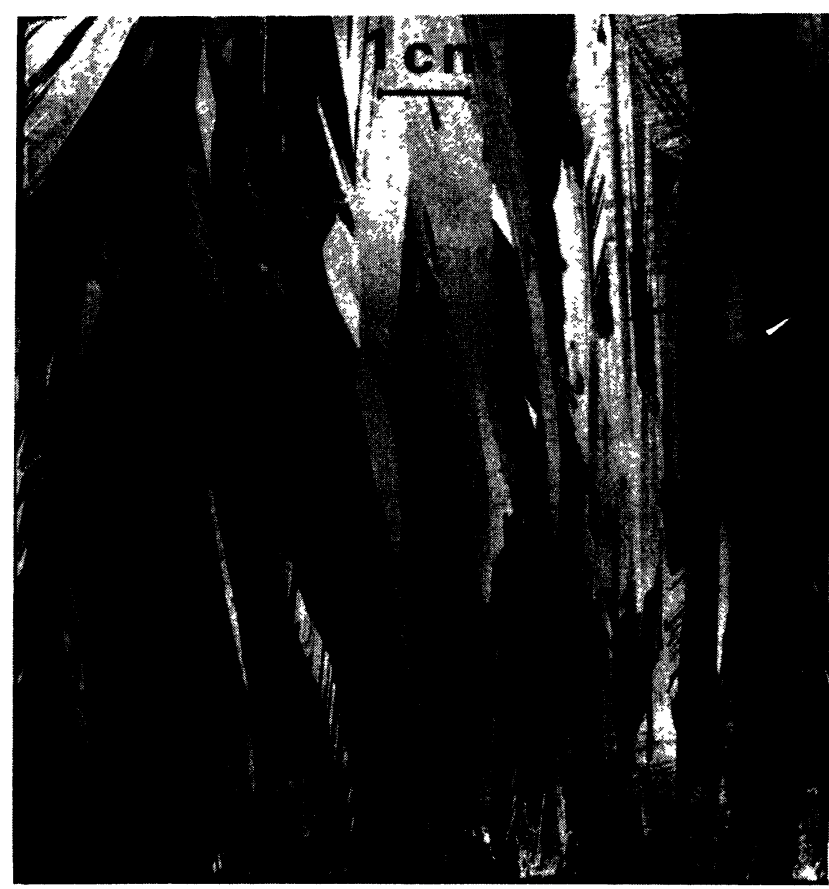

Fig. 1. - Structure colonnaire caractéristique d'une solidification unidirectionnelle.

[Typical columnar structure for an unidirectional solidification.]

The choice of morphological parameters depends on the mean size of the grains and the shape. As can be seen in figures $2 a$ and $3 a$, the solar cells show simultaneously small and very large crystals of irregular shapes. In order to prevent a bias in the quantitative measurements, it is necessary to eliminate those particles which intersect the frame of measurements [1]. If one works at low magnification, it is not possible to detect the small crystals and thus to carry out measurements on them. On the other hand at very large magnification, the large crystals cut the frame of measurements and are then eliminated. To avoid this scale problem, it is necessary to use certain parameters of mathematical morphology, such as the function $P(l),[1,4]$.

This function $P(l)$ corresponds to the probability of a segment $l$ being included in the grain. The variation in length of this structuring element $l$ enables the change in the different size of crystals to be followed. The size distribution functions of the chord length, $l$, are given by the following equations [5] :

$$
\begin{aligned}
F(l) & =\frac{P^{\prime}(0)-P^{\prime}(l)}{P^{\prime}(0)} \\
G(l) & =\frac{P(0)-P(l)+l P^{\prime}(l)}{P(0)}
\end{aligned}
$$

with

$F(l)$ : the size distribution function of the chord lengths, in number,

$G(l)$ : the size distribution function of the chord lengths, in weight,

$P(0)$ : the value of the function $P(l)$ at the origin, $P^{\prime}(l)$ : the derivative of the function $P(l)$.

As an example, the function $P(l)$, the size distributions in number $F(l)$ and in weight $G(l)$ are given in figures $2 b, c, d$ and $3 b, c, d$. It can be seen that the curve $G(l)$ takes better into account the effect of large crystals on the size distribution.

\section{Materials.}

Two polycrystalline silicon ingots (POLYX) were chosen to present the following results. Two solar cells $\left(\mathrm{n}^{\circ} 5\right.$ and 50$), 45 \mathrm{~mm}$ apart in the direction of solidification, were taken from the ingot 2020-9 with a homogeneous structure and analysed (Fig. 2). Three solar cells were taken from an other ingot (1118-1) with a more heterogeneous structure : $n^{\circ} 29$ and $\mathrm{n}^{\circ} 49$ were $20 \mathrm{~mm}$ apart, and $\mathrm{n}^{\circ} 11870 \mathrm{~mm}$ apart (Fig. 3) (the solar cells are numbered successively from the top to the bottom of the ingots, and for parallel sections from outside to inside).

The function $P(l)$ is the measure of the intersected aera between the original grain and its image translated by the structuring element $l$.

\section{Results.}

Both size distribution curves in number $F(l)$ and in weight $G(l)$, for the different solar cells, confirm well the high degree of homogeneity of the ingot 2020-9 (Fig. 2) and also the variation in the morphology of the ingot 1118-1 (Fig. 3). The morphological parameters measured are given in table I.

The distribution curves, $F(l)$ and $G(l)$, have a general shape similar to that observed previously [6]. The slope of the curves varies strongly from the various solar cells analysed of the ingot 1118 . It has been established that the slope at the origin is a function of the angularity of the grains and the number of small grains $[4,5]$. Consequently for the same ingot and taking into account the columnar structure of the grains, which ensures essentially the same grain shape, the slope at the origin is a precise measure of the number of the small grains. This parameter can be then used to detect possible secondary nucleation which may occur during solidification.

\section{Simulation.}

Using an automatic image analyser such as the LeitzTAS, it is possible to store the initial structure in 


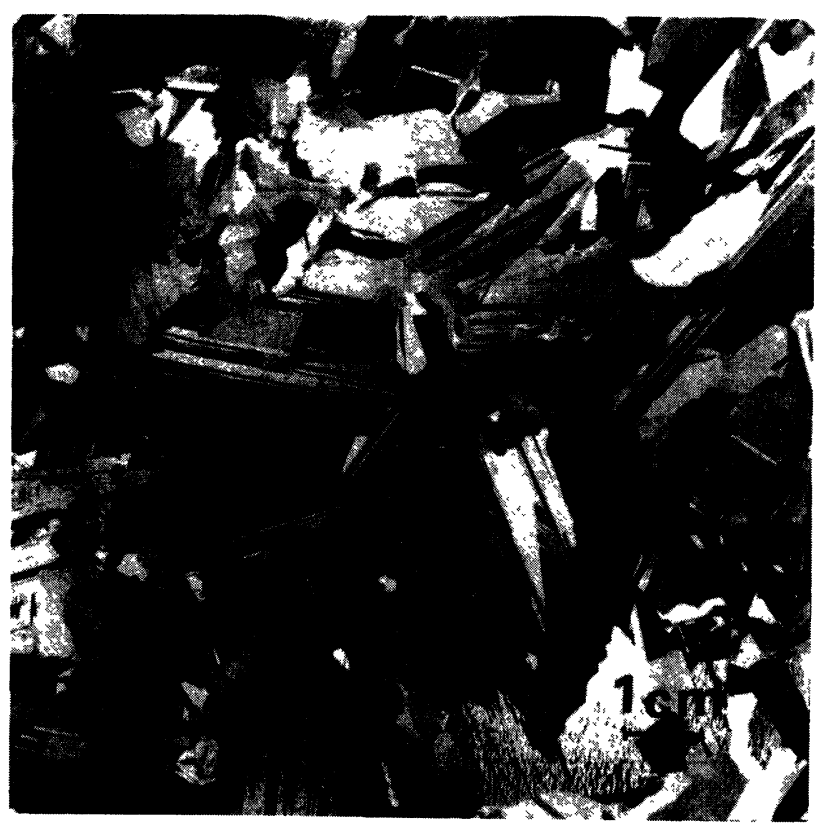

a)

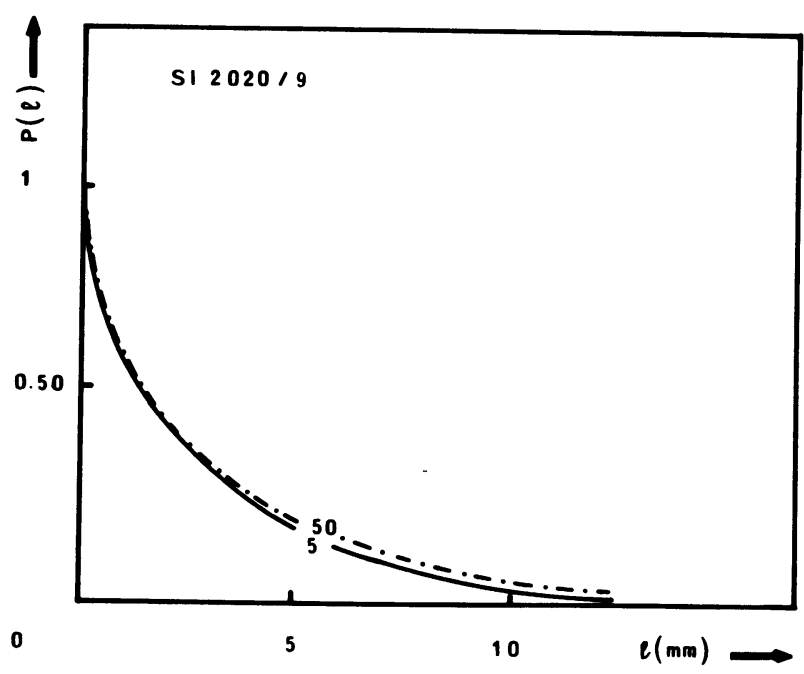

b)

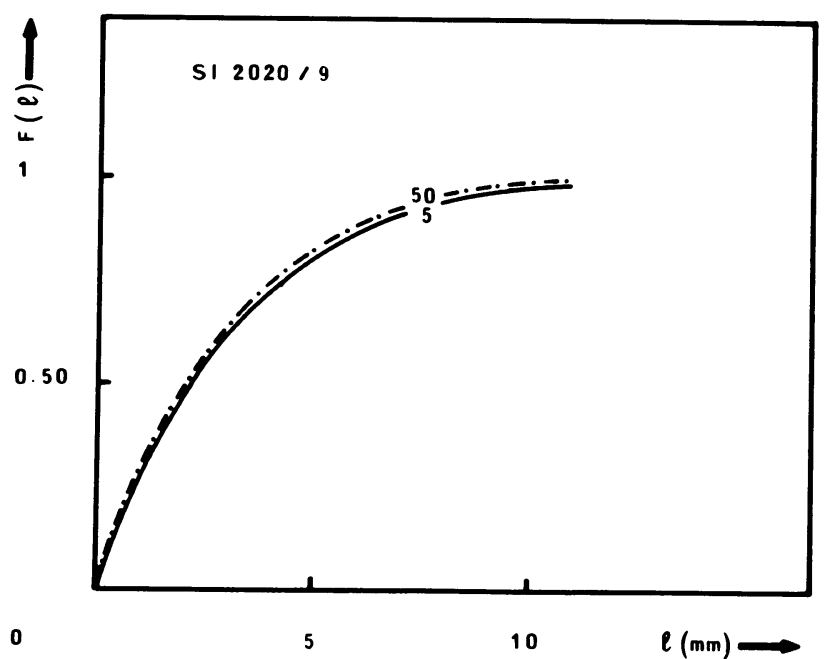

c)

Fig. 2. - Lingot 2020-9/50: a) Micrographie optique du quart d'une cellule solaire; b) La fonction $P(l)$; c) Distribution de la taille en nombre $F(l)$; d) Distribution de la taille en mesure $G(l)$.

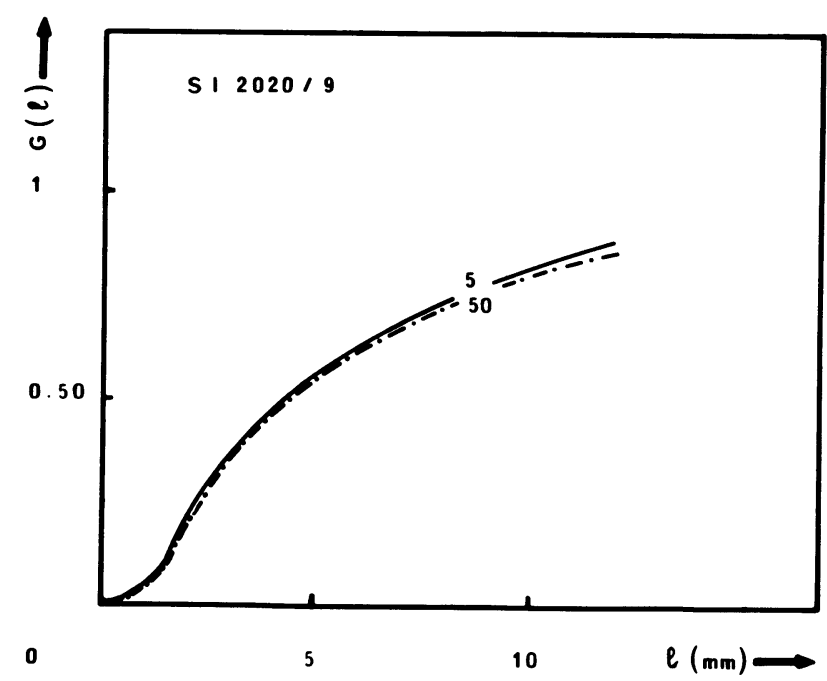

d)

[Ingot 2020-9/50: a) Optical micrograph of the quarter of a solar cell ; b) Function $P(l)$; c) Size distribution in number $F(l)$; d) Size distribution in weight $G(l)$.] 


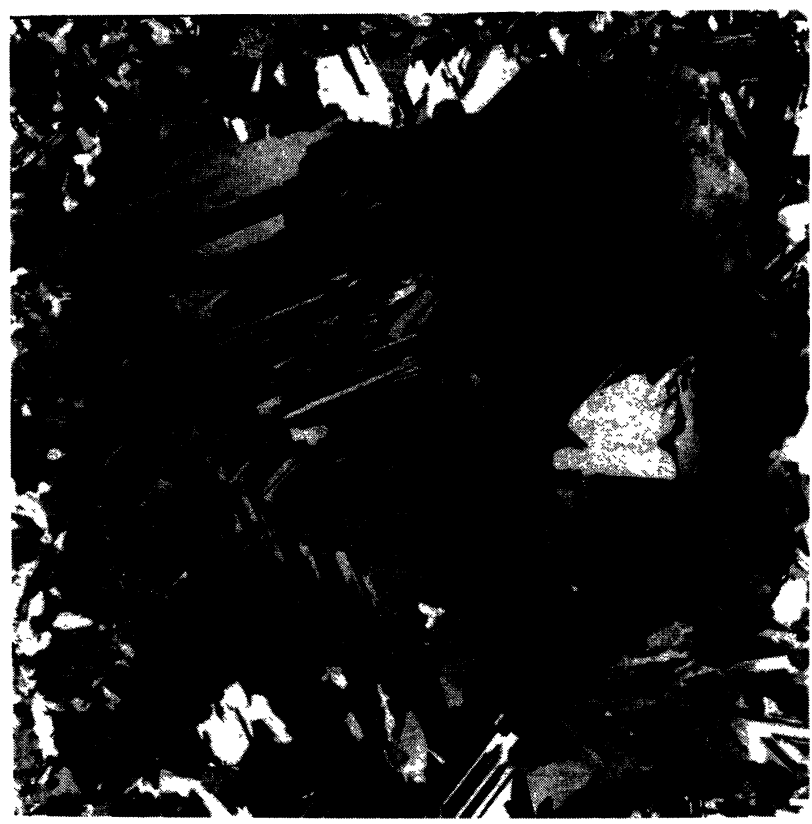

a)

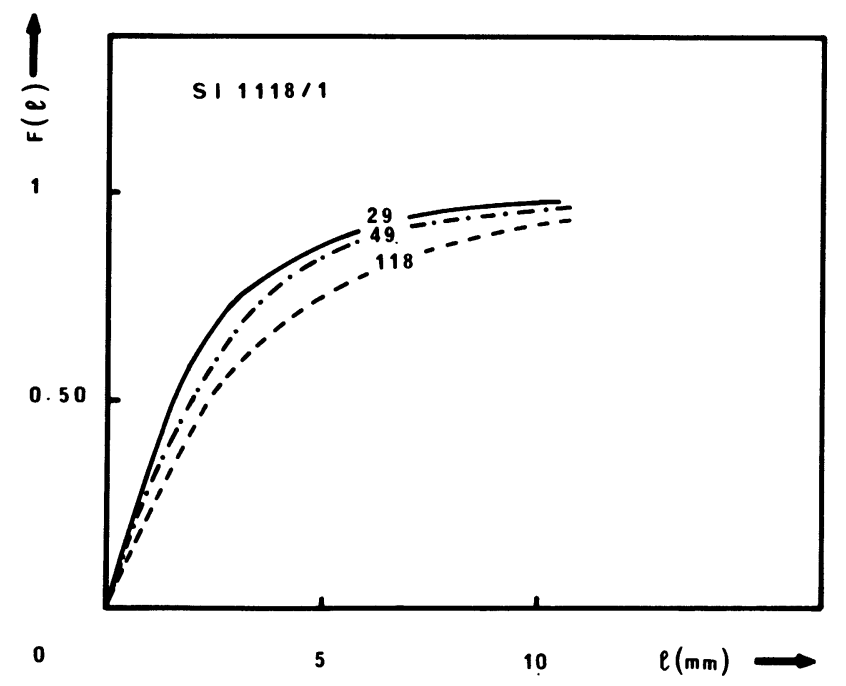

c)

Fig. 3. - Lingot 1118-1/29 : a) Micrographie optique du quart d'une cellule solaire; b) La fonction $P(l)$; c) Distribution de la taille en nombre $F(l)$; d) Distribution de la taille en mesure $G(l)$.

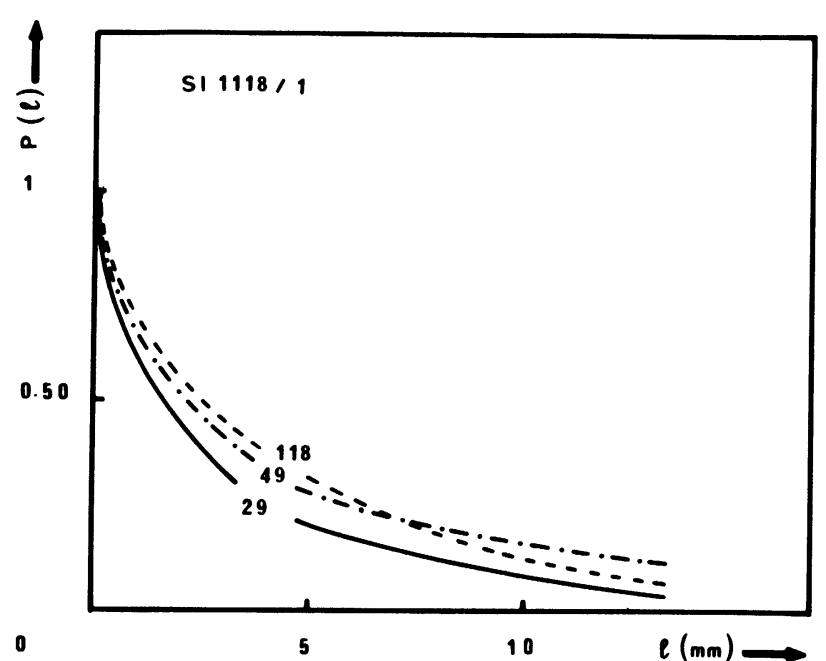

b)

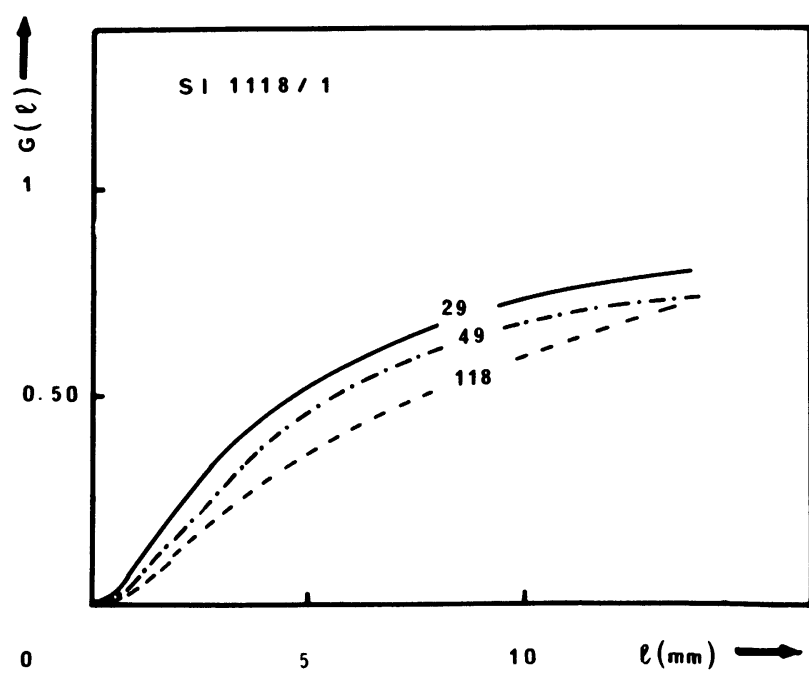

d)

[Ingot 1118-1/29: a) Optical micrograph of the quarter of a solar cell ; b) Function $P(l)$; c) Size distribution in number $F(l)$; d) Size distribution in weight $G(l)$.] 


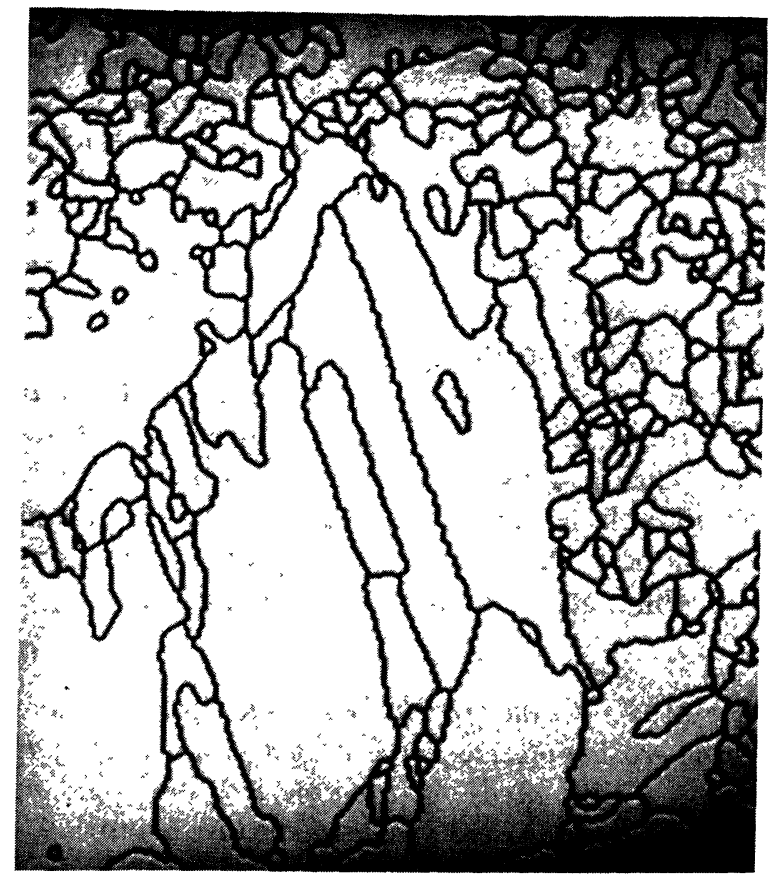

a)

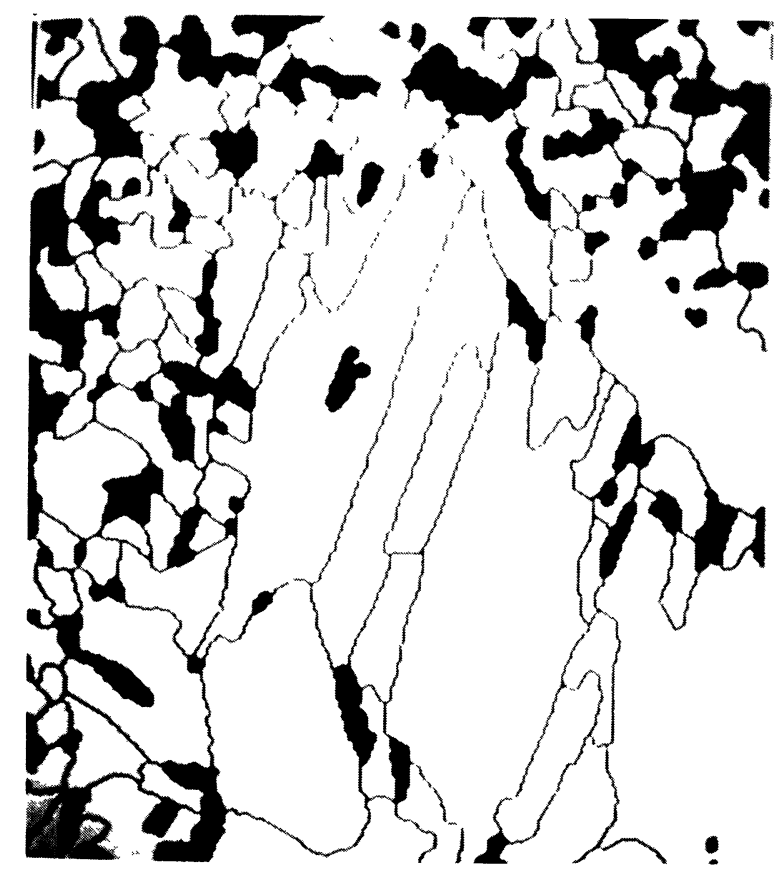

c)

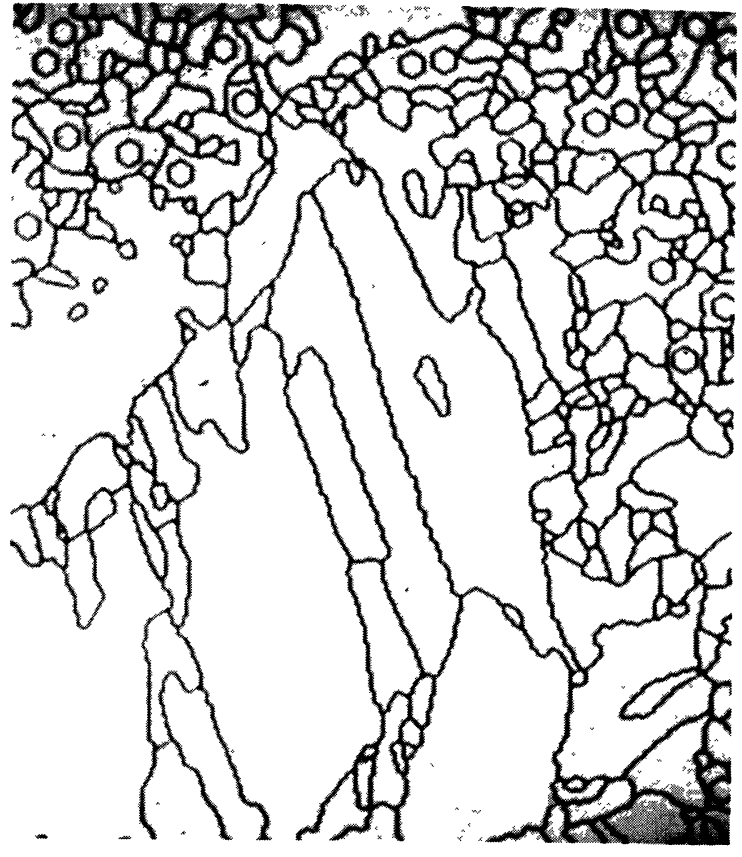

b)

Fig. 4. - a) Structure initiale en mémoire ; b) Implantation de vingt germes ; c) Erosion de petits grains de taille équivalente.

(a) Initial structure in memory; b) Implantation of 20 nuclei ; c) Erosion of the small grains with equivalent size.] 
Table I. - Values of the morphological parameters : mean chord length in weight, mean chord length in number, initial value of the slope $b$ at the origin of the $\mathrm{G}(l)$ function and initial value of the slope $b$ at the origin of the $\mathrm{F}(1)$ function for the different solar cells analysed.

\begin{tabular}{|c|c|c|c|c|}
\hline $\begin{array}{c}\mathrm{N}^{\circ} \\
\text { cell }\end{array}$ & $\begin{array}{c}\text { Mean chord } \\
\text { in weight } \mathrm{mm}\end{array}$ & $\begin{array}{c}\text { Mean chord } \\
\text { in number } \mathrm{mm}\end{array}$ & $\begin{array}{c}\text { Slope at } \\
\text { the origin G(1) }\end{array}$ & $\begin{array}{c}\text { Slope at } \\
\text { the origin F(1) }\end{array}$ \\
\hline $2020 / 9 \mathrm{n}^{\circ} \mathrm{S}$ & 6.1 & 2.9 & $3.83 \mathrm{E}-02$ & 0.26 \\
$2020 / 9 \mathrm{n}^{\circ} 50$ & 6.7 & 2.8 & $3.76 \mathrm{E}-02$ & 0.28 \\
& & & & \\
\hline $1118 / 1 \mathrm{n}^{\circ} 29$ & 8.2 & 2.7 & $6.71 \mathrm{E}-02$ & 0.37 \\
$1118 / 1 \mathrm{n}^{\circ} 49$ & 12.1 & 3.3 & $4.51 \mathrm{E}-02$ & 0.29 \\
$1118 / 1 \mathrm{n}^{\circ} 118$ & 10.8 & 4.1 & $3.12 \mathrm{E}-02$ & 0.26 \\
& & & & \\
\hline
\end{tabular}

memory (Fig. 4a) and to implant in the structure an increasing number of nuclei of a given size. In order to test the effect of secondary nucleation we have only implanted a small number of grains. Thus 20 nuclei implanted in a field of measurement of $2300 \mathrm{~mm}^{2}$ correspond to a concentration $1.12 \%$ (Fig. 4b). It is possible to obtain new size distribution curves, $G(l)$ and $F(l)$ based on the modified structure and also to study the change in the various morphological parameters, and, in particular, the slope at the origin, $b$, using the approximation $y=a x^{2}+b x+c$.

The obtained values for the two ingots with nuclei added - 10, 20 and 40 - are given in table II. It can be seen that a reduction in the mean chord length

Table II. - Values of the same morphological parameters than in table I after implanting several nuclei $\mathrm{n}$.

\begin{tabular}{|c|c|c|c|c|c|}
\hline $\begin{array}{c}\mathrm{N}^{\bullet} \\
\text { Cell }\end{array}$ & $\begin{array}{c}n \\
\text { nucles }\end{array}$ & $\begin{array}{l}\text { Mean chord } \\
\text { in weight } \\
\mathrm{mm}\end{array}$ & $\begin{array}{l}\text { Mean chord } \\
\text { in number } \\
\mathrm{mm}\end{array}$ & $\begin{array}{l}\text { Slope at } \\
\text { the origin } \\
G(1)\end{array}$ & $\begin{array}{c}\text { Slope at } \\
\text { the origin } \\
F(1)\end{array}$ \\
\hline \multirow[t]{4}{*}{$2020 / 9 n^{\circ} 5$} & On & 6.07 & 2.94 & $3.83 E-02$ & 0.26 \\
\hline & $10 n$ & 6.01 & 2.81 & $5.06 \mathrm{E}-\mathrm{C2}$ & 0.28 \\
\hline & $20 n$ & 5.89 & 2.69 & $6.24 E-02$ & 0.29 \\
\hline & $40 n$ & 5.70 & 2.49 & $8.48 \mathrm{E}-\mathrm{C} 2$ & 0.33 \\
\hline \multirow[t]{4}{*}{$2020 / 9 n^{\circ} 50$} & On & 6.69 & 2.85 & $3.76 \mathrm{E}-02$ & 0.28 \\
\hline & $10 n$ & 6.58 & 2.74 & $4.48 E-02$ & 0.30 \\
\hline & $20 n$ & 6.52 & 2.62 & $6.33 \mathrm{E}-02$ & 0.31 \\
\hline & $40 n$ & 6.33 & 2.41 & $8.79 E-02$ & 0.33 \\
\hline \multirow[t]{4}{*}{$1118 / 1 n^{\circ} 29$} & On & 8.24 & 2.68 & $6.71 \mathrm{E}-02$ & 0,37 \\
\hline & $10 n$ & 8.24 & 2.56 & $8.14 \mathrm{E}-02$ & 0.39 \\
\hline & $20 n$ & 8.15 & 2.46 & $9.50 \mathrm{E}-02$ & 0.40 \\
\hline & $40 n$ & 7.98 & 2.27 & 0.11 & 0.41 \\
\hline \multirow[t]{4}{*}{$2118 / 1 n^{\circ} 49$} & On & 12.06 & 3.32 & $4.51 \equiv-02$ & 0.29 \\
\hline & $10 n$ & 12.05 & 3.15 & $5.95 \mathrm{E}-02$ & 0.32 \\
\hline & $20 n$ & 12.01 & 3.01 & $7.22 \mathrm{E}-02$ & 0.34 \\
\hline & $40 n$ & 12.00 & 2.78 & $9.69 E-02$ & 0.39 \\
\hline \multirow[t]{4}{*}{$1118 / 1 n^{\circ} 118$} & $O_{n}$ & $10.8 \mathrm{C}$ & 4.08 & $3.12 \mathrm{E}-02$ & 0.26 \\
\hline & $1 c_{n}$ & 10.76 & 3.45 & $\therefore .47 \mathrm{E}-02$ & 0.29 \\
\hline & $20 n$ & 10.55 & 3.65 & $5.45 E-02$ & 0.31 \\
\hline & $\because 0 n$ & 10.51 & 3.31 & $7.63 \mathrm{E}-\mathrm{C} 2$ & 0.37 \\
\hline
\end{tabular}

takes place with increasing the number of nuclei. The slope, $b$, increases markedly with increasing the number of additional nuclei. This was observed for the different solar cells studied. It is therefore a parameter very sensitive to the presence of new small crystals.

Since these experiments were carried out on real solar cells, we have made the reverse operation, i.e. eliminating (by erosion) the grains of equivalent size to those implanted, taking care to reconstruct the zone eroded to prevent the formation of fictitious pores. This is shown in figure $4 c$ and the results are given in table III. A relationship between the change in the slope at the origin and the proportion of small grains eliminated can then be determined.

Table III. - Values of the morphological parameters after an erosion of size 3 (the grains with a size smaller than 3 are eliminated) for the different solar cells analysed. In our case size 3 is equivalent to $1.2 \mathrm{~mm}$.

\begin{tabular}{|l|l|c|c|c|c|}
\hline $\begin{array}{l}\mathrm{N}^{\circ} \\
\text { cel1 }\end{array}$ & $\begin{array}{c}\text { \% of } \\
\text { grains }\end{array}$ & $\begin{array}{c}\text { Mean chord } \\
\text { in weight } \\
\mathrm{mm}\end{array}$ & $\begin{array}{c}\text { Mean chord } \\
\text { in number } \\
m m\end{array}$ & $\begin{array}{c}\text { S1ope at } \\
\text { the origin } \\
\mathrm{G}(1)\end{array}$ & $\begin{array}{c}\text { Slope at } \\
\text { the origin } \\
\mathrm{F}(1)\end{array}$ \\
\hline $2020 / 9 \mathrm{n}^{\circ} 5$ & $4 \%$ & 6.5 & 3.5 & $8.51 \mathrm{E}-03$ & 0.11 \\
$2029 / 9 \mathrm{n}^{\circ} 50$ & $5 \%$ & 7.2 & 3.5 & $2.30 \mathrm{E}-02$ & 0.10 \\
& & & & & \\
\hline $1118 / 1 \mathrm{n}^{\circ} 29$ & $6 \%$ & 9.0 & 3.6 & $7.42 \mathrm{E}-03$ & 0.12 \\
$1118 / 1 \mathrm{n}^{\circ} 49$ & $4 \%$ & 12.7 & 4.0 & $1.03 \mathrm{E}-02$ & 0.13 \\
$1118 / 1 \mathrm{n} \cdot 118$ & $3 \%$ & 11.5 & 4.95 & $7.43 \mathrm{E}-03$ & 0.09 \\
\hline
\end{tabular}

\section{Discussion and conclusion.}

Based on the results presented it can be seen that certain parameters of mathematical morphology well describe the morphology of polycrystalline silicon, despite the effect of scale which is always present. The slope at the origin of the distribution curve in number, $F(l)$, is a parameter very sensitive to the presence of small grains, providing that the grains have more or less the same shape from one solar cell to the other. The measurement of the slope at the origin can therefore be used to detect secondary nucleation during solidification of polycrystalline silicon ingot. Thus in the case of the ingot 2020-9 with homogeneous microstructure, the results presented show the presence of the beginning of a secondary nucleation, the slope changing very little between solar cells $n^{\circ} 5$ and 50 . On the other hand in the case of ingot 1118-1 with a very heterogeneous microstructure, the strong decrease in slope at the origin for solar cells $n^{\circ} 29, n^{\circ} 49$ and then $n^{\circ} 118$ shows that there was appreciable secondary nucleation.

The slope at the origin of the size distribution curves in number is therefore a parameter which takes into account changes in secondary nucleation and which is very sensitive to the presence of small 
crystals. It is a parameter which can therefore be used in studies of nucleation and solidification of metallurgical or ceramic structures, to better understand the mechanisms of solidification.

\section{References}

[1] Coster, M., Chermant, J. L., Précis d'Analyse d'Images (Ed. CNRS) 1985.

[2] Fally, J., Guignot, D., Symposium on Poly-microcrystalline and amorphous semiconductors, EMRS, June 1984, Strasbourg (France), ed. by P. Pinard, S. Kalbitzer (Ed. de Physique, les Ulis) 1984, p. 199.

[3] Lauvray, H., Lay, P., Nouet, G., Donon, J., Proc. of the VIth European Photovoltaic Solar Energy Conference, April 1985, London,
(England) (Ed. by D. Reidel, Publ. Company) 1985, p. 901.

[4] SERrA, J., Image Analysis and Mathematical Morphology (Academic Press) 1982.

[5] Matheron, G., Eléments pour une Théorie des Milieux Poreux (Ed. Masson) 1967.

[6] Chermant, J. L., Coster, M., LAy, P., Nouet, G., IVth European Symposium for Stereology IV ESS, August 1985, Acta Stereol. 5 (1986) 299. 